Narrative Works

Issues, Investigations, \& Interventions

\title{
Ancestry, Place[s], and Identity in Spiritual Direction Narratives
}

\section{Janet Kathryn Ruffing}

Volume 8, Number 1-2, 2018

URI: https://id.erudit.org/iderudit/1059850ar

DOI: https://doi.org/10.7202/1059850ar

See table of contents

Publisher(s)

Centre for Interdisciplinary Research on Narrative, St. Thomas University

\section{ISSN}

1925-0622 (digital)

Explore this journal

\section{Cite this article}

Ruffing, J. (2018). Ancestry, Place[s], and Identity in Spiritual Direction Narratives. Narrative Works, 8(1-2). https://doi.org/10.7202/1059850ar

\section{Article abstract}

In this 2017 John McKendy Memorial Lecture, Dr. Janet Ruffing, RSM, discussed spiritual direction as a narrative process, recognized or not, in which the directee tells his or her sacred tale in the interaction with a spiritual director who significantly affects the unfolding of this serial narrative of lived faith. At a time, when directees have unprecedented access to genealogical information and also live in or make retreats in a variety of places, how do these new experiences affect their identity spiritually and socially? Do they become integrated into the ongoing narrative of identity or not?
This document is protected by copyright law. Use of the services of Érudit (including reproduction) is subject to its terms and conditions, which can be viewed online.

https://apropos.erudit.org/en/users/policy-on-use/ 


\title{
NARRATIVE WORKS \\ Issues, Investigations, \& Interventions
}

\section{OUTSIDE THE BOX}

\section{Ancestry, Place[s], and Identity in Spiritual Direction Narratives ${ }^{1}$}

\author{
Janet Kathryn Ruffing, RSM \\ Yale Divinity School
}

In this 2017 John McKendy Memorial Lecture, Dr. Janet Ruffing, RSM, discussed spiritual direction as a narrative process, recognized or not, in which the directee tells his or her sacred tale in the interaction with a spiritual director who significantly affects the unfolding of this serial narrative of lived faith. At a time, when directees have unprecedented access to genealogical information and also live in or make retreats in a variety of places, how do these new experiences affect their identity spiritually and socially? Do they become integrated into the ongoing narrative of identity or not? [Video Link]

I have been interested in stories and storytelling most of my life. We live in a storied world, whether we notice it or not. From our earliest conscious lives, we hear stories about ourselves, our families, our communities, our cultures, our ancestors in faith, and about our place in these stories. My mother was our family storyteller and the keeper of ancestral stories. She also exemplified for us how one could change one's own narrative. She began college and then a teaching career when my brother and I were close to our own college years, before such mid-life transitions were common. When the elementary school principal she worked for as a secretary recognized the teacher in her and encouraged her to enroll in the local community college, she decided to fulfill a long-

1 On October 19, 2017, Dr. Janet Ruffing, RSM, presented the 10th annual John McKendy Memorial Lecture on Narrative at St. Thomas University. The annual lecture, sponsored by the Centre for Interdisciplinary Research on Narrative (CIRN), is named for John McKendy, PhD, who died tragically in 2008. He was a member of the Sociology Department at St. Thomas University and one of the founding members of CIRN. Dr. Ruffing has graciously permitted Narrative Works to publish the transcript and video of her lecture.

NARRATIVE Works: IsSUES, INVESTIGATIONS, \& INTERVENTIONS 8(1/2), 83-98

CJanet Kathryn Ruffing, 2018 
deferred desire, initiating the next chapter of her life, which would last 17 years.

If we are fortunate, we might also hear and read stories that are about people, cultures, and religions that differ from ours. Even better is the experience of meeting such people first-hand, as we did through our Mom's classmates at California State University in San Francisco. We discover through stories and our own experience the difference culture makes and the difference that ethnicity, race, gender, religion, wealth, or sexual orientation make in our lives and in those we meet. Many of us take these experiences and our narrative process for granted, as well as the fact that we primarily understand ourselves through the stories we tell about ourselves as well as the stories of those who differ from us.

As a 20-something Sister of Mercy in California during the late 1960s, I was an English and religion teacher in Catholic secondary schools before I began my doctoral studies in spirituality more than 10 years later. I was astounded to discover that the literature about the burgeoning field of spiritual direction rarely alluded $t$, regardless of what else it is and what explicit model of direction the director espouses. The spiritual direction process unfolds in stories. It was obvious to me that directees were creating their oral spiritual autobiographies from session to session, revising their inherited story in the light of new experience, and creating new chapters in their spiritual lives as we went along (Ruffing, 2010, pp. 21-22).

Narrative theologians offered some clues, psychotherapists were beginning to incorporate narrative theories into their work and continue to do so today, and hermeneutics accounted for some of these narrative processes (Gadamer, 1975; Holland, 2006; Parker, Huff, \& Pahls, 2009). This interdisciplinary work brought attention to the role of narrative in the formation of identity. Our identities appear to be narrative creations that we rehearse over our lifetimes, revising and adapting them to account for "new experiences" (Gadamer, 1975; Tilley, 1985); the new selfunderstanding results from these changes. ${ }^{2}$ To use religious language, conversion may not be too strong a word to point to major changes in our sense of self and our orientation to reality. This is particularly true in relationship to changes in our denominational stories and interpretations

\footnotetext{
${ }^{2}$ Gadamer (1975) emphasizes a generosity of openness in a genuine conversation to seek the meaning of a text or a situation mutually. These are the conditions required in the coforming of narrative representations of personal and religious experience in spiritual direction (pp. 319, 330-333). Tilley (1985) places autobiographical storytelling within the larger religious and cultural myths people absorb from their cultures (p.17).
} 
of Scripture which provide an explicitly religious world view within which we create our own sacred stories. Our stories take place within other stories. But so, too, do various stage theories of psychological development or growth describe ordinary, age-specific, psychological maturing.

Since our self-understandings are always partial and limited by the level of our maturity when we developed our core stories, we may overlook or neglect the significance of some actual events and our responses to them that we can understand and appropriate only later. Think about what we may not understand about a situation simply because we were children. Have you ever sat down at the family table and discovered that no one else remembers what you do? When we arrive at increasingly nuanced understandings of our identity narratives, we may become free to revise longstanding assumptions about "what happened" that contributed to this identity and begin to fashion a new, more complex, and nuanced autobiographical story. ${ }^{3}$ In the context of spiritual direction, we can define this particular narrative as an episodic, spiritual autobiography, co-created within the narrative opportunity of the spiritual direction conversation (Ruffing, 2010, pp. 321-345). ${ }^{4}$ This may be one of the few non-pathologized or stigmatized conversations possible because it is a faith story, contextualized within a larger faith story.

Today there are new insights and experiences that inform our sense of self - what we may have learned about our ancestry, either genetically or historically; the places or landscapes that have shaped us; and, in many places in the world, competing narratives about our national myths. These impel those of us who can manage this level of self-critical reflection to revise our stories or to "get another story" from the abundance of available stories that can redeem our personal and collective past and free us to create more fulsome identities that align with our moral compass and support our growth in grace and in God's life in us.

\footnotetext{
3 "Autobiographical memories are about selves interacting with others in the world. Individual narratives come to life in social interactions imbued with cultural meaning. When we share our experiences with others through narrative, we share ourselves, but these selves are already integrated in social and cultural frames for narrative identities. Narrating our personal past connects us to ourselves, our families, our communities, our cultures" (Fivush, Habermas, Waters, \& Zaman, 2011, p. 340). See also McAdams (2006).

${ }^{4}$ See especially Chapter 5 of Ruffing (2010, pp.131-142) for more elaboration on this characterization of stories taking place within other stories.
} 
Let me make this more concrete. For those who have explored their ancestry or genetic inheritance, we can ask ourselves, "What do we know?" and "How do we feel about it?" When we get into it, we may not be too sure we want the information. If we are honest, none of us has a completely exemplary background. Our family histories are complex, incomplete, and not necessarily accurate, nor are any of us the product of a perfect family. But these stories served a useful purpose of placing our lives within a larger familial context. The stories we share are often highly selective - usually those that flatter us, uncritically justify past ancestral choices, and enhance our sense of self. Some of the omissions are unintentional and others are not. We tend to like the good bits and leave out the problematic ones. We have access to records today that previously would have taken much time, energy, and considerable financial resources to pursue. And some information was deliberately "lost," forgotten, or creatively "reinterpreted" under the pressure of immigration and complicated life situations. Everyone did not put the whole story down on their immigration documents even if they knew what it was.

White family histories are a microcosm of European and North American colonial history, and they are nested within our specific cultural histories. My own includes primarily early British colonialist adventures and a later immigration caused by massive crop failure near the city of Trent and German Imperialism in the late $19^{\text {th }}$ and early $20^{\text {th }}$ centuries, which led to some Austrian and Scandinavian immigration as well. Canadians share a similar history on the British side, while the French colonial history affects Canada nationally more strongly than it does the U.S. And both countries have an ambiguous, troubled, and unresolved relationship with our First Nations Peoples.

Recently, I have been wondering what is different about Canadian history and culture that has enabled you to collectively acknowledge the injustice of your treatment of First Nations Peoples in gestures of reconciliation, while our national myth supports our continuing mistreatment of Native Americans when members of the dominant, EuroAmerican culture want resources that lie in protected lands or the lands themselves. In addition, both Americans and Canadians are now far more ethnically diverse than ever before, as we have welcomed immigrants in the $20^{\text {th }}$ and $21^{\text {st }}$ centuries from Asia, Latin and South America, the Middle East, and increasingly, the African subcontinent. This suggests we will continue to incorporate a greater variety of ancestral stories into that of our countries and our dominant national mythic story. 
In the U.S., suddenly, some white people think they are endangered and must close borders and reignite an old pattern of American nativism that has periodically emerged in our national history when those newcomers in the late $19^{\text {th }}$ and early $20^{\text {th }}$ centuries were southern Europeans. This response was based on skin colour, ethnicity, and religion-olive-skinned southern Europeans, and Catholic Irish in the $19^{\text {th }}$ century, and now Muslims, Asians, and Latin and South Americans. We forget that we took considerable land from Mexico. It is a blatant form of racism and religious intolerance which exposes attitudes and expectations rooted in "white privilege" that appear to be threatened. It seems to be an experience of those, who have unconsciously benefited from this "white privilege" since colonial times, to be confronted with its taken-for-granted systemic aspects that have only partially unraveled since the end of our Civil War and who have received an intentionally substandard education reinforcing these views. Thus, the myth that justifies these attitudes and behaviours is widely shared in an uncritical manner and reinforces the personal identities of those who incorporate it into their personal stories (McAdams, D., 2006; McAdams \& McLean, 2013).

On the popular and political level, at present, we seem to have some mysterious amnesia about how our actions militarily, economically, and ecologically all over the world contribute to this immigration. In fall 2017, the upsurge of aggressive white supremacy and its anti-Jewish and racist ideology has not been seen in such public display since the 1960s. Some narratives of hate and exclusion go underground, only to resurface when perceptions of exclusion, economic distress, and substandard education lead some susceptible people to call for exclusion, while they feel completely "innocent" about the systemic racism which has not yet been dismantled in the U.S., although the discriminatory behaviour of many has changed. Legal frameworks have been created to prohibit such discriminatory behaviour, but that has not necessarily changed people's internal narratives about it. The law has changed, but the story has not. This is a sad and disturbing time, because prominent governmental leaders evoke and reinforce this deeply flawed narrative and fail to offer an alternative national narrative or model the behaviour it requires, based on our founding ideals and principles of inclusion into which we are still growing.

We appear to be deeply confused about the distinctions between the storylines about who we are and aspire to be, which convey our inclusive, civic, and national ideals, and those which are based on 
"alternative facts," as shorthand for ahistorical, fact-free, false narratives which are proving to be more stubborn than those based on actual events, historical or scientific fact, let alone on morality and mutual respect for difference. It matters deeply how we tell the story, who tells the story, and how well we are educated in "alternative stories" (Dunne, 1991b, p. 21).

It is a leap of consciousness to be able to recognize there are alternative stories, when we also need to acknowledge within a Christian context that we have appropriated and misappropriated Biblical texts in ways that support these false narratives. Conservative Catholics and some white Evangelicals read biblical texts selectively and preach them in ways that refuse to accept legitimate diversity, the rights of others, and freedom of conscience in contested moral issues. The prosperity Gospel bears little resemblance to the actual teachings of Jesus and is devoid of any sense of the common good as an essential principle of social justice which extends beyond private morality. The same Gospel, however, inspired the Amish community in Pennsylvania and African-Americans to forgive the perpetrators of hate-filled men who murdered children at their own school and men and women gathered in a Christian Bible Study in Charlotte, North Carolina. These stories continue to stir us because they call us to a genuinely Gospel way of life.

Within Catholicism, more than fifty years after Vatican II, we continue to experience a conflict of interpretations of this global reorientation of Catholic faith and practice to the heart of the Gospel. These include a sense of world church; the rights and dignity of women; the necessity and right to follow one's own informed conscience; a robust ecumenism and interfaith dialogue; and social justice teachings which critique unbridled global capitalism, indiscriminate use of military force, and the harm done to our common home as we refuse to protect the very conditions of human life on a sustainable earth.

I leave it to you to critique the conflicts within your own appropriations of the Gospel in your traditions and the way this plays out

\footnotetext{
${ }^{5}$ In a companion work, Dunne (1991a) provides a set of spiritual guidelines for "Dynamics of Story," in which he identifies the way we tend to reinforce in our behaviour a story that includes ourselves, or accept the role someone else has given us in their story. "Affectively," he says, "a clear sign of a false or incomplete story is that it leaves us feeling alone, stranded, anxious, confused, afraid, resentful or bitter." On the other hand, "a true story always leaves us feeling centered, humble, honest, alive, and in touch with the world around us. It may not be a 'pleasant story.' It may be a story of suffering or even of our own sin; but if we meet our negative experiences with integrity, we sense that we are living in the truth of our souls" (p. 171).
} 
in relationship to economic, environmental, and respect or not for various forms of diversity. We are, indeed, in "over our heads," as Robert Kegan so aptly pointed out, developmentally and religiously, if we are insufficiently educated to deal with the complexity of our world and its web of interconnections (cited in Tinberg \& Weisberger, 1998). ${ }^{6}$ Consequently, we require more sophisticated stories, not less sophisticated ones, because of the complexity of our interconnected world. Adequate, age-appropriate education is usually required to achieve these adult capacities for reflection our complex societies require. Otherwise, the narratives within which many adults live cannot change. How stubborn these received stories remain, despite new information!

Shifting from the current distressing distortion of the U.S. national story to personal and familial stories, I want to illustrate reframing and re-understanding a couple of examples from my own family history. My grandmother, who was mostly Scandinavian, told a story well into her 90s, that soon after her mother died when she was 8 or 9, her father, a "rough carpenter," moved the family from Tacoma, Washington, to a homestead in Okanogan, Washington. She recounted that a man rode up to their place on horseback and asked her father if he had a daughter he could spare, because his wife needed help in the kitchen. And her father said, without consulting her, "You can have Edie." She was packed up and rode off on the back of this stranger's horse a few hours later. So she lost not only her mother, but also her older siblings, who were 18 and 19 years old. Grandma would say, "What kind of father would give his daughter to a stranger without even meeting the woman she was supposed to help?" This was not the only

\footnotetext{
${ }^{6}$ Tinberg and Weisberger (1998) reprise Kegan's theory in relationship to traditional college-age students who may not have progressed to the level of abstract thinking in which they can reflect on their own beliefs, acts, or on the world as a whole. Kegan calls this the cross-categorical principle of meaning making, in which they can think abstractly and reflect on their emotions and ideas (p. 45). Kegan also points to the next stage adults may reach, the inter-individual, in which we see ourselves as part of a complex system (p. 46). This stage enables us to be reflective on our own meaningmaking system and that of others, which allows one to work together to reconcile differences. This stage seems to have developed because of the complexity of modern life, where change is constant and diversity is a fact of life. There is yet a final stage, the transystem or dialectical stage, that requires our giving up possession of our own system for a new one that includes one's own and that of others (p. 46). Tinberg and Weisberger suggest that many community college students may not have developed the capacity for abstract thinking that adulthood in complex societies requires, and offer a case study demonstrating how a college class can facilitate this development.
} 
uncomplimentary story about my great-grandfather, which leads me to believe there was some truth in this assessment, but it was not the whole story. It was certainly all she knew, and she somehow managed to survive it, but it caused her to question the character of her father in the light of other observed behaviours, as well.

My brother, who spends far more time on our genealogy than do I, found census records online that suggest a surprisingly different interpretation. The census shortly after that incident revealed that Jens was listed as a "carpenter," living nearby, and only the older siblings, a sister and brother, were on the homestead. If the homesteading were succeeding, Jens would have been there and not working for wages elsewhere. If my grandmother had known that her father might have been trying to provide for her wellbeing, rather than abandoning her to strangers, she might have felt differently about him and this painful and alienating separation from her siblings. But it haunted her well into her 90s.

To offer another personal story of being affected by recently discovered ancestry information, Edith married my grandfather, who was a Folsom. We have a three-volume Folsom family history that goes back to about 50 years after the establishment of Massachusetts Bay Colony. John Folsom and his family were involved in desecrating the Anglican Church in Hingham, England, and after paying fines, sailed with about fifty others involved in this incident to settle in Hingham, Massachusetts. In the U.S., every Folsom is interrelated in some way. My grandparents, however, were economically insecure and barely managed to survive the Great Depression during the 1930s in the west, even though my grandfather was a skilled worker. Having grown up in the west in a modest middle-class family, I have never had pretensions to privilege.

Education was highly valued, but my parents both attended a business school, because they could not afford college, and married within the year. My mother earned her BA at California State University, San Francisco, when I was in the $9^{\text {th }}$ grade. My brother earned his $\mathrm{PhD}$ in economics at Columbia University about nine years after our mother graduated from college, but at the time, I did not know Columbia was an Ivy League school or what that represented.

When visiting my brother, Ken, one Christmas vacation, he opened Geni.com and said let's look at the New England branch of the family. When I was hired by Yale in 2010, there were many times I wondered how I ended up here. When I proclaimed the Gospel in the First Congregational Church in New Haven for a student's ordination, I 
wondered how the Divines felt about this Roman Catholic sister in their pulpit while I was proclaiming the long Gospel passage of Lazarus and Dives. When Ken and I looked at the genealogy, we discovered we were $11^{\text {th }}$ cousins to Elihu Yale, who had donated the land for this divinity school.

This unexpected information suggested that maybe I did have some familial "right" or destiny to be at Yale. What I tend to minimize in this story is the fact that I had a 23-year history of graduate teaching at Fordham University, a tier-one research institution; a solid publication record; and held the rank of a tenured full professor. I am also only the second Catholic sister to teach in the Divinity School. Although I have enjoyed my work at Yale and the many new experiences I have had there, my values as a Catholic sister lead me to sit lightly with this prestigious appointment. Before this ancestral discovery, I had already chosen not to attach to the deference and privilege which comes to me purely by the fact of this appointment. I have been valued at Yale because of the quality of my teaching, the field the school wanted to add to the curriculum, my widely ecumenical background, and my years of experience teaching international students from all over the world, the majority from Africa and Asia while at Fordham.

These features of my profession are more important to me than the "privilege" that comes from working in this elite institution. For me, this is a conscious ethical and spiritual choice. My ancestry does not make me a better, more faithful Christian. My life and my choices do that. I enjoy my work with my students and faculty colleagues, but I have not raised my standard of living, because I am a Sister of Mercy and live accordingly. I do enjoy the cultural and educational opportunities that come with this appointment. When I retire and return to California, the privilege will be over, and these ten or so Yale years will recede into the background, except for the memories of the many students whose lives I have influenced in significant ways. In my life story, this will likely be the last chapter of my graduate academic career. And another chapter of my overarching story as a Sister of Mercy will begin in California, after 34 years on this coast.

From the perspective of spiritual direction, how I think about and relate to this current experience is less about unearned, ancestral privilege and more about the conscious choices which define my character and the consistent daily experience of how God's grace and compassion move in and through me in unexpected and surprising ways at school. This is a narrative of grace, of how God opened my way to both of my post- 
doctoral appointments, when I personally preferred to stay on the west coast and applied three times to west coast universities when I was caring for my parents from New York. This is a narrative of mission, of character, and of hard work, which I take for granted. In this professorial role, I have been able to support the growth in grace and spiritual maturity of students and others in my community to a fuller appropriation of relationship with God and their personal vocations. These are the themes that appear in my personal spiritual direction narratives - the story of grace and Spirit that unfold in this social location have little to do with my ancestry, which was certainly more accidental than causal. But it is entirely possible that ancestry might figure more strongly in the direction narratives of someone else. I believe we will perhaps be judged less by our ancestry than by how we have lived our lives in relationship to it, whatever shape that life story might have taken. What really matters are the personal choices we have made in relationship to our ancestry and other opportunities.

\section{Places/Landscapes}

The spiritual tradition relates to the physical geography of our lives in complex and interrelated ways. Each of us is shaped profoundly by our natal environment and by the physical places where we have lived. Within Christian theology, the natural world is our home and a place in which we often experience God. The creation is God's first sacrament and is universally available to every human being, regardless of religion or beliefs. Of itself, the natural world needs us to tell its story of cosmic unfolding, as well as to tell the story of grace when our personal theophanies occur in specific landscapes and are mediated through the natural world.

In Christian theology, God reveals Godself through the natural world. And this natural world is God's first and universal revelation to all peoples. ${ }^{7}$ Specific places become "sacred" because of our felt sense of connection with and communication with God there. God, as experienced in Judaism and Christianity, is not limited to one place, while at the same time, God can reveal God's presence, or not, in specific places.

Anthropologist Keith Basso (cited in Christie, 2013), studied the Apache peoples' place names and 'their role in holding and bodying forth the entire history of the people. To say the name of a place, to tell a story about a place, is to waken memory, conjure up everything that ever

\footnotetext{
${ }^{7}$ See Ruffing (1997), and for a Reformed perspective, Lane (1998).
} 
happened there, and make it present again to the community" (p. 115). In this culture, these memories "become woven into the personal and collective identity of the people" (p. 115). Further, Basso notes: "Places possess a marked capacity for triggering acts of self-reflection, inspiring thoughts about who one presently is, or memories of who one used to be, or musings on who one might become" (p. 116).

Robert Adams (cited in Christie, 2013), writing about landscape photography, suggests something quite similar. These pictures offer three truths: "geography, autobiography, and metaphor" (p.116). Altogether, "the three kinds of information strengthen each other and reinforce what we all work to keep intact-an affection for life" (p. 116). We can know places scientifically-know the names of the flora, fauna, geological features in an objective and abstract way. But we relate to these places through an "experiential place sense" (p. 116). This is the imaginative, affective response to a place that allows it to become significant for a person or community.

It seems to me that this experiential place sense is at work in the way we tell stories about the geographical and urban places where we have lived and where we have encountered God within our own embodied histories. These places require us to tell their stories and to connect our spiritual sensibilities and experiences with these sacred places.

A geologist or biologist can recognize the ecological history of a place over time from informed observation. But that story of earth processes is not the same as our stories about the way these places and what has happened to us in them continue to shape us in bodily and spiritual ways. Ulric Neisser (1988) identified this sense of self as "the ecological self" which is present in us from infancy. It is our sense of self with respect to our physical environment. This sense of self expands through autobiographical consciousness and becomes part of our identity when we weave stories of places into our narratives.

From the perspective of spiritual practice and of spiritual direction, this significance of a sacred sense of place in our lives continues to unfold over time. Each of us has an embodied sense about what kinds of places have nourished our deep connection to God. We remember the different kinds of events that happened in these placessacred encounters, relationships, and the changes in the sense of our physical selves in the process.

For those of us who grew up in coastal places, the ocean is a balm to our souls, including the rhythm of the surf, the salty air, the effect on us 
of fog or sun on a given day, the sensation of the sand under our feet and bodies, water lapping over our feet on the shore, and the thrill of body surfing or floating or swimming in the salt water, which must evoke the comfort of prenatal life in our mother's womb. Our senses immediately respond to these features of place when we arrive.

I lived with another Sister who found making a retreat by the ocean was destabilizing for her and made her restless. She had grown up in the Rocky Mountains, and her sacred sense of God was related to the stability of the mountains and the rootedness of the trees, not the constantly changing rhythms of coastal surf and sand. Since we were both in California at the time, the immensity of the ocean and rhythms of the surf seemed more spiritually significant to me than the mountains. While I can appreciate the transcendent sense of forest and mountains, the open expanses of beautiful coastal areas are my spiritual home.

Anyone who has directed retreatants at a retreat house hears an incredible variety of stories of grace uniquely related to each directee and the natural features of the place. Many retreatants make similar discoveries as retreatants who have preceded them. Others have utterly unique experiences of that landscape as a place of God's presence and self-revelation. It is always important to explore with directees what their sense of that place is and how they relate it to their embodied story of grace.

Today, some of us are consciously living in a new story of the universe and have developed an ecological sensibility about nature. Although for some, this non-theistic story-which is often, nonetheless, full of mystery - suffices for their orientation to this reality, there is an incredible creativity in Christian theology today accounting for this return to what was once called the "Book of Nature." These developments include new conversations between theologians and scientists, as well as the retrieval and reinterpretation of neglected themes in Scripture, in ways of imaging God in whose likeness we are made, and in an ethical sense of how all the peoples of the earth share a common home for which we are responsible to preserve and share. For these directees, it is important to help them make connections between the universal story of this evolving and still mysterious universe and their religious traditions.

\section{Identity}

Various contemporary theories about narrative suggest that our identities are, at their core, narrative accounts of ourselves to ourselves as 
well as accounts of ourselves to others. These others may be a spiritual director, a family member, a therapist, a psychologist, a friend, or some other trusted person. Most of us, over time, organize our sense of ourselves through key stories that represent significant events and realizations about ourselves and the kind of person we have become or aspire to become.

We rehearse these to ourselves internally if we are highly introverted and in conversation with multiple others if we are more extroverted. It is almost as if we draw on a "playlist" of key events in our lives that we use to describe the kind of person we are that seems appropriate to each interlocutor. We might share one set of stories with acquaintances, others with close friends, still others with a spiritual director, and others with family members who think they know our narrative identities already because of shared experiences. We try to get the "audience" right and are selective about what we disclose to others.

The narrative situation greatly affects how much we will let others into our identity narratives. Writing classes are one place where many young people begin to formally engage in this process. Various forms of faith-sharing groups may provide such a narrative situation for this kind of sharing. And spiritual direction is another opportunity in a one-on-one situation in which adult directees entrust their sacred tales to a spiritual director without an expectation of equal sharing. In other words, directees are free to focus directly on their unique stories of grace, at whatever stage of adult and spiritual development they have achieved, facilitated by the interest of the director and the invitations for further elaboration that may elicit the "unsaid" which can be storied.

There is, of course, so much more that can be said about spiritual direction and identity. In this paper, I am presuming some familiarity with some of my earlier work on narrative and spiritual direction, and I wanted to develop in more detail the two themes I have explored with you. First, ideas related to new discoveries about ancestry or genetics, to which many directees have access, and which require some form of assimilation and critical reflection about how they affect a directee's sense of self and destiny, imaginatively or realistically, if at all. Second, the role of place or landscapes in the conscious sense of our identities and spiritual experience. Neisser asserts this ecological sense of self is present in infancy but does not elaborate how this figures in adult experience of our sense of self or how it might be related to our sacred history. My suspicion is that this is more significant for many of us than we realize. Missionaries have told me that, when they are adjusting to a new 
geographical location and culture, that their first sense of being at home there is their relationship to the features of the place itself. The sky is still overhead, the ground beneath their feet, and the landscape mediates experience of God in this new place, even before they can make themselves understood in the new language or feel at home in the new culture.

When directees come for spiritual direction, they have had an experience which they have not yet coherently storied, even for themselves. Sometimes these experiences just spring into consciousness in a session. Directees are surprised by the story they had no intention of telling today, because it emerged from experience that was not yet fully appropriated. Elsewhere, I have developed these ideas about how the emergence of our spiritual identities, our selves before God, or as we understand this deepest core of ourselves, continually rings changes on our autobiographical sense of ourselves. The telling of our deepest relational, spiritual, and existentially challenging experiences contributes to restorying our identity narratives over time. Today, that may include more conscious awareness of the influence or not of ancestry and landscapes on our spiritual and cultural identities.

These stories of our unfolding identities are not only a co-creation with the spiritual director but even more importantly, they are "cocreated, coauthored with God and neighbor" (Thomas Cooper, cited by Ruffing, 2012, p. 69). In spiritual direction, the director is both audience and at the same time a profound influence on the narrative of self the directee elaborates over time. These narratives may be identified as "searching" narratives as life continues to unfold (Roger Haight, cited in Ruffing, 2012). ${ }^{8}$ As directees "not only create searching narratives, they are also from time to time caught up in the Mysterious Holy One who can never be adequately storied by us but who changes and transforms our consciousness mystically beyond our self-referent narrative of ourselves. This is not an identity that can be collapsed into our ordinary narratives of spiritual identity" (Haight, cited in Ruffing, 2012, p. 72).

These stories of self and God are characterized by greater and greater coherence and complexity commensurate with adulthood. In this place of greater complexity and adequacy of a coherent spiritual narrative identity, further transformation originates from beyond ourselves,

\footnotetext{
${ }^{8}$ In reference to the Spiritual Exercises, Haight says that each person "may appropriate this narrative uniquely into one's own on-going searching narrative with holistic, comprehensive, and integrative" results (cited in Ruffing, 2012, p. 71).
} 
drawing us further into Mystery. Are we, as spiritual directors, attentive to this lure drawing us?

\section{References}

Christie, D. E. (2013). The blue sapphire of the mind: Notes for a contemplative ecology. New York, NY: Oxford University Press.

Dunne, T. (1991a). Spiritual exercises for today: A contemporary presentation of the classic spiritual exercises of Ignatius of Loyola. San Francisco, CA: Harper, 1991.

Dunne, T. (1991b). Spiritual mentoring: Guiding people through spiritual exercises to life decisions. San Francisco, CA: Harper.

Fivush, R. Habermas, T., Waters, T., \& Zaman, W. (2011). The making of autobiographical memory: Intersections of culture, narratives, and identity. International Journal of Psychology, 46 (5), 321-345.

Gadamer, H. (1975). Truth and method. G. Barden \& J. Cumming (Eds. \& Trans.). New York, NY: Crossroad. (Original work published 1960)

Holland, S. (2006). How do stories save us? An essay on the question with the theological hermeneutics of David Tracy in view. Louvain Theological and Pastoral Monographs 35. Leuven, Belgium: Peeters/Eerdmans.

Lane, B. C. (1998). Landscapes of the sacred: Geography and narrative in American spirituality. New York, NY: Paulist Press.

McAdams, D. (2006) The redemptive self: Stories Americans live by. New York, NY: Oxford University Press.

McAdams, D. P., \& McLean, K. C. (2013). Narrative identity. Current Directions in Psychological Science, 22(3), 233-238.

Neisser, U. (1988). Five kinds of self-knowledge. Philosophical Psychology, 1(1), 3559.

Parker, K. L., Huff, P. A., \& Pahls, M. J. G. (2009). Tradition and pluralism: Essays in honor of William M. Shea. Lanham, MD: University of America.

Ruffing, J. K. (1997). "To have been one with the earth": Nature in contemporary Christian mystical experience. Presence, 3, 40-50.

Ruffing, J. (2010). To tell the sacred tale: Spiritual direction and narrative. Mahwah, NJ: Paulist Press.

Ruffing, J. K. (2012). Spiritual identity and narrative: Fragmentation, coherence, and transformation. Spiritus, 12, 63-74.

Tilley, T. (1985) Story theology. Theology and Life Series 12, Collegeville, MN: Liturgical Press.

Tinberg, H., \& Weisberger, R. (1998). In over our heads: Applying Kegan's theory of development to community college students." Community College Review, 26(2), 43-56.

Janet Kathryn Ruffing, $\mathrm{PhD}$, a Sister of Mercy, is Professor Emerita of Spirituality and Spiritual Direction at Fordham University, where she directed the spiritual direction program from 1986 until her arrival at Yale Divinity School in the spring of 2010. She has published five books and numerous articles on spiritual direction and supervision, mercy spirituality, female religious life and leadership, kataphatic mysticism, prayer, and other technical 
topics in spirituality. She has lectured or given workshops in the U.S., Canada, Australia, New Zealand, France, the U.K., Ireland, India, Thailand, the Philippines, Korea, Hong Kong, and Macau. She was a founding member of Spiritual Directors International and is past president of The Society for the Study of Christian Spirituality. She has also chaired the mysticism group in the AAR, been an associate editor for The Way, and on the Editorial Board for Presence. She has experience in teaching religion and English in secondary schools, in the formation of spiritual directors, permanent deacons, and women religious. 